\title{
English Language Teachers' Perceptions of Using ICT in Teaching in Cycle Three in the United Arab Emirates*
}

\author{
Ali Hussein H. Mohammed, Abdurrahman Ghaleb Almekhlafi \\ United Arab Emirates University, Al-Ain, Abu Dhabi, United Arab Emirates
}

\begin{abstract}
This study examined "Cycle Three" English language teachers' (ELTs) perceptions of their Information and Communicative Technology (ICT) competencies and use of technology in Abu Dhabi Education Council (ADEC) schools in the UAE (United Arab Emirates). The study was conducted on 73 randomly selected male and female Cycle Three English language teachers. Participants were native and non-native of different years of experience in teaching English language. A questionnaire and observations were adapted from the National Educational Technology Standards (NETS) for Teachers and Performance Indicators. Results were analyzed using Statistical Package for the Social Sciences (SPSS) and the constant comparative method of data analysis. Study findings suggested that English language teachers in Cycle Three had low perceptions of their ICT competencies. Recommendations are discussed.
\end{abstract}

Keywords: competencies, perceptions, ICT, instruction, teacher attitudes, English education, planning, UAE schools

\section{Introduction}

The United Arab Emirates (UAE) leadership recognizes the importance of ICT and the role teachers play in getting the most from it in their classrooms. According to the results of a survey released by the Telecommunications Regulatory Authority (TRA), the UAE is considered "the top performing country in ICT among the Arab states" (Telecommunications Regulatory Authority, 2009). Abu Dhabi Education Council's (ADEC) New School Model (NSM) document (2009-2018) has paid a lot of focus on teachers' awareness and proper usage of ICT by "Consistently resourcing schools with instructional materials in the areas of Arabic and English literacy, math, science, consumables, active learning, and ICT" (p. 2). Teachers' awareness of their ICT competency is vital since it can empower or hinder ICT in English language teaching and learning.

Since ADEC's introduction of the NSM (2009-2018), concerns have been raised regarding teachers' awareness and proper usage of ICT. It seems, however, that neither administrators nor teachers have a clear vision and guidelines to help them perceive their ICT competency to assess, develop, and modify their practices in using ICT. Carmen, María del Carmen, Emilio, Eloy, and Mar (2003) said that recognizing the ICT tools'

\footnotetext{
* Acknowledgements: This manuscript is a part of an MA thesis submitted to College of Education, United Arab Emirates University under the title "Secondary School English Teachers' Perceptions of their ICT Competency in Teaching EFL in the UAE”.

Ali Hussein Haidar Mohammed, English language instructor and graduate student, United Arab Emirates University, Al-Ain, Abu Dhabi, United Arab Emirates.

Abdurrahman Ghaleb Almekhlafi, associate professor of Educational Technology, Ph.D., College of Education, United Arab Emirates University, Al-Ain, Abu Dhabi, United Arab Emirates.
} 
effect on teaching can help in increasing the students' competencies and improve language learning especially with their speaking skills.

The UAE pays a lot of focus on the role of ICT in education represented by preparing the infrastructure, facilitating their usage, and purchasing the latest ICT tools. ADEC's Strategic Plan (2009) emphasized providing an ICT technology-rich learning environment to enable equitable opportunities to students to use technology in meaningful and authentic tasks that develop their various learning skills.

However, in the UAE context, studies involving Cycle Three English language teachers' perceptions of their ICT competencies are minimal. In a research conducted by Almekhlafi and Almeqdadi (2010) investigating teachers' perceptions of technology integration in UAE school classrooms, results showed that teachers highly perceive their ICT competency in technology integration, especially in model schools as the mean scores ranged from 4.0 to 4.8 on a 5-point scale. Notably, female teachers showed an overall higher perception of their ICT integration than the male group.

Similarly, Ismail, Almekhlafi, and Al-Mekhlafy (2010) investigated teachers' perceptions of the use of technology in teaching languages in UAE schools. They studied both Arabic and English teachers' ICT perceptions. Results showed the importance of the role of teachers' ICT perceptions in first and second language teaching and learning. Results also indicated that teachers confirmed the inevitable impact of technology on their own teaching practices which promote students' language learning.

\section{Operational Definitions of Terms}

Information and Communication Technologies (ICTs): ICT in this study means all ICT tools that are available and accessible by English language teachers including all hardware and software to facilitate English language teaching and learning listed in the questionnaire developed for this study.

ICT Competencies: ICT competencies in this study refer to the thorough knowledge and skills to fully operate, use, and manipulate ICT tools in English language teaching and learning in addition to having good comprehension of the up-to-date ICT tools targeting English language teaching and learning.

ICT Perceptions: ICT perceptions in this research refer to the extent to which English language teachers recognize ICT tools positively or negatively and use to be consistent with the cultural context of the Emirati society and public schools.

Teachers' ICT Attitudes: Teachers' ICT attitudes in this study refer to the way teachers' behave towards ICT tools positively or negatively whether they implement or reject those tools as measured by the questionnaire developed for this study.

Teachers ICT Standards: Teachers' ICT standards in this study refer to a set of criteria that teachers have to reach and master to be able to handle ICT tools perfectly according to their English language teaching and learning situation needs.

\section{Literature Review}

\section{The Role of ICT in Teaching}

Over 219 studies have addressed the use of ICT in education and have consistently found that learners in technology-rich environments experienced positive effects on performance in all subject areas (Ya'acob, Nor, \& Azman, 2005; So \& Paula, 2006). Research conducted on teachers' readiness for ICT, proposed that teachers still need a long time to improve before their schools will be able to take full advantage of the opportunities offered by 21 st century technology (Ya'acob et al., 2005). 
Several researchers have examined the effective role of ICT in language teaching situations. For example, Tella, Toyobo, Adika, and Adeyinka (2007) examined 700 Nigerian secondary school teachers' use of ICT and implications for further development of ICT use in schools. The results showed that the majority of the instructors perceived ICT as very useful in facilitating teaching. According to Tella et al., ICTs utilized by teachers was clearly intended to be used to help learners study well and that perceived usefulness was also strongly linked to those intentions. Teachers should tailor their ICT use to meet all individuals' needs. They should be aware that ICT needs to be tied to precise needs of learners and avoid the "one size fits all" approach and encourage learner-centered teaching (Leach, 2005, p. 112).

\section{ICT and English Language Learning.}

Al-Mekhlafi (2004) studied the effect of one ICT software, an Interactive Multimedia (IMM) CD-ROM on the language achievement of sixth grade students in relation to their learning styles. Results displayed no significant differences between the control group and the experimental group in overall achievement. One of the recommendations stated in the study was that IMM should be examined as an individualized learning tool.

In another study, Almekhlafi (2006a) examined the effectiveness of computer-assisted language learning (CALL) on learning English as a foreign language by elementary school students in the United Arab Emirates. The results of an analysis of variance (ANOVA) showed a significant difference between CALL users and non-users in favor of the experimental group.

In another study, Almekhlafi (2006b) investigated the effects of interactive multimedia as ICT tools on students' achievements in English as a foreign language. Although the results did not show significant differences between the achievements of the control group (paper-based learning) and the experimental group (Interactive Multimedia users), significant difference within the experimental group is tracked depending on the students' different cognitive learning styles. Field-independent students seemed to benefit more from the treatment than field-dependent. This important discovery demonstrated a significant orientation that should be taken into account when tailoring ICT tools to meet the different cognitive learning styles of the students to achieve effective technology integration. One of the results was that technology integration can enhance student-centeredness alleviating the role of the teacher. More recently, Bahrani's (2011) study showed that exposure to video materials improved speaking performance for English language students more than the social interaction for ESL (English as a Second Language) students.

\section{Teachers' ICT Competency}

In a similar study, Simonsson (2004) indicated that the utilization of technology is related to teachers' beliefs and attitudes about the use of this tool, and the extent to which other teachers employed technology in their teaching. A marginal result demonstrated that bilingual teachers believed that technology might assist them to incorporate cultural issues to clarify important points.

Eugene (2006) studied how teachers' attitudes, perceptions, and beliefs may have an effect on technology integration in their classrooms. Results indicated that teachers' beliefs and perceptions may correlate with their teaching practices and the implementation of technology. Al-Zaidiyeen (2010) explored teachers' attitudes and levels of technology use in classrooms in Jordan. Results indicated that teachers had a low level of ICT use for educational purposes. However, teachers held positive attitudes towards the use of ICT and a significant positive correlation between teachers' level of ICT use and their attitudes towards ICT were found. 
Knezek and Christensen (2002) analyzed several major cross-cultural studies related to ICT in education completed during the 1990s. They suggested several stages for teachers' advancement in technology integration. They mentioned that changing teachers' attitudes is more important than ICT skills.

Educational stakeholders still perceive the lack of ICT competency, knowledge, and skills of teachers as a major obstacle to the perception of their ICT-related goals (Pelgrum, 2002).

Scrimshaw (2004) stated that using ICT does not lie in presenting and using ICT, but rather in its function as a contributor towards a learner-centered form of teaching and learning. Using ICT tools represented mainly by the computer helps to decontextualize the learning process, which is the main goal of the teaching process.

Selvi (2010) stated that teachers' ICT competencies depend on using tools and technical equipment for reaching, distributing, and transferring the knowledge. They comprise any ICT tool that helps to produce, manipulate, store, communicate, and/or disseminate information.

This new trend of using ICT in the UAE, which is part of using multi-methods in teaching languages, depends mainly on the teacher's ICT competency hoping to facilitate students' learning skills as they encounter them on a daily basis. Native and non-native English teachers need to be fully aware of the required ICT tools, techniques, limitations, and programs that help them provide the learners with language learning authentic situations to develop their language learning.

The use of ICT also enhances recalling previous learning, providing new stimuli, activating the learner's response, and providing systematic, steady feedback and providing access to rich sources in learning. Tella et al. (2007) found that the use of the computer by teachers was due to their intentions to use it and that awareness of the usefulness was also strongly linked to those intentions.

Teachers who lack the chance to cope with the current needs of developing professionally in the use of modern ICT feel under threat and may lose their jobs as integrating ICT in teaching is part of teachers' evaluation way and be competitive.

\section{Teachers' Attitudes and Perceptions}

As a new educational innovation, the implementation of ICT into education is a complex process where many factors play a role. Pelgrum (2001) assumed that teachers and students in the teaching-learning situation play a significant role in facilitating or hindering changes that are outside the control of the decision makers of education.

Albirini (2004) studied attitudes of high school English as Foreign Language (EFL) teachers in Syria toward ICT. The study examined the relationship between computer attitudes and five independent variables: computer attributes, computer competence, cultural perceptions, computer access, and personal characteristics including computer training background. The findings suggest that teachers have positive attitudes toward ICT in education. Teachers' attitudes were predicted by computer attributes, cultural perceptions, and computer competence.

Al-Rabaani (2008) investigated the knowledge, skills, and attitudes of Omani social studies teachers' use of computers in instruction. Findings revealed differences in teachers' computer skills and attitudes towards using computers according to the region and stage they teach, but there were no differences according to gender.

A key feature of teachers' attitudes towards ICT is their understanding of how it will benefit their students and enhance their work. M. J. Cox, Preston, and K. Cox (1999) expressed the need to measure teachers' beliefs 
and understanding of the role of ICT within the subject being taught. Kirkup and Kirkwood (2005) distinguished innovators who are enthusiastic about technology as a valuable tool from adopters who are less interested in technology and need evidence that it will improve their lives or work. Hermans, Tondeur, van Braak, and Valcke (2008) shed light on the mediating role of teachers' educational beliefs in the resistance and receptiveness to integrate computers in classroom practice. Mumtaz (2000) concluded in a meta-analysis that teachers' theories about teaching are central in influencing teachers to use ICT in their teaching. Teachers' educational beliefs can be barriers to ICT integration.

Several researchers have mentioned that the successful implementation of ICT in education depends largely on the perceptions of the teachers (Jimoyiannis \& Komis, 2007; Wen \& Shih, 2008). They are the ones who determine how the ICT tools are used in the learning situations. Bullock (2004) found that teachers' perceptions play a major positive or negative role in the adoption of technology. Likewise, Kersaint, Horton, Stohl, and Garofalo (2003) stated that teachers who have positive attitudes toward ICT feel more comfortable with using it and usually integrate it into their practices.

\section{Theoretical Framework}

Constructivist learning theory indicates the role of ICTs as active construction of new knowledge based on a learner's prior experience. Hence, learning is an active process affected by the ICT tools used by teachers during the instruction. Constructivism Theory is a good fit for working towards establishing well-equipped teachers with meaningful ICT usage so they can ensure learning among learners. Constructivism focuses on the importance of a gradual knowledge construction built by the teacher using different ICT skills and tools. This trend was also supported by research conducted by Harman and Koohang (2005), and Hung and Nichani (2002) who focused on the importance of steady knowledge building where ICT teachers' ability saves time and effort.

Other theories such as Media Richness theory (Daft \& Lengel, 1984; 1986; Trevino, Lengel, \& Daft, 1987) also highlighted the importance of using ICT for facilitating the teaching and learning situations. This theory argues that media represented by ICT competency on the teachers' part plays a crucial role in learning provided that teachers use the appropriate media to enable effective learning to take place. Since most of the learning takes place via communication, the ICT tool facilitates a shared understanding between the teacher and the learners and among the learners themselves.

\section{Statement of the Problem}

It is clear from the Strategic Plan of the Abu Dhabi Education Council (2009) and ADEC's New School Model document (2009-2018) that competency with ICT tools is a real focus. It seems that perceptions and attitudes toward ICT tools are essential for their proper use, guidance, assessment, development, and modification of Cycle Three English language teachers' practices in using ICT.

The current ADEC educational reform of ICT presentation to schools has not been accompanied by research targeting Cycle Three English language teachers, native and non-native perceptions of their ICT competencies. Consequently, the problem this study tries to address is that such lack of concentration on the end-users' attitudes may cause an unwelcomed attitude towards ICT in ADEC schools. Most studies conducted in the UAE context, however, used surveys and interviews. Such methods might not reflect the actual teachers' ICT perceptions and competencies. Classroom observations definitely could give a clearer picture of the actual implementation of these tools in teaching. 
Teachers need to be well skilled in ICT and have positive perceptions towards it. This study aims at helping English language teachers become more aware of their perceptions of ICT competence in addition to highlighting the best practices implemented by English language teachers.

\section{Purpose of the Study}

The purpose of this study is to explore ADEC's Cycle Three English language teachers' perceptions of their ICT competencies in teaching the English language. These can play a major role in their language instruction and highly affect their performance, positively and/or negatively (Harman \& Koohang, 2005; Hung $\&$ Nichani, 2002).

This study also aims to help all stakeholders at Abu Dhabi Educational Council (ADEC) to be familiar with Cycle Three teachers' perceptions of their ICT competencies and helps decision-makers plan for purchasing the needed ICT tools for teaching and learning. It is also intended to give teachers of English a clear idea of their perceptions of the ICT competencies. Moreover, it is intended to help students accelerate their language achievement more easily and be more enjoyable. In addition, teachers need a basic level of competency in ICT to meet the increasing demand for having teachers fully aware of competency in operating the educational system which requires strong and efficient professional awareness of their competency including ICT skills. Finally, it is also important for policy-makers to be aware of teachers' current ICT competencies, to foster strong areas and overcome weaknesses to enhance English language teaching and learning.

\section{Significance of the Study}

The ability to use ICT tools effectively to teach English language and handle various ICT tools purposefully has become an essential need for English language teachers. The current study is significant since it investigated English language teachers' perceptions of their ICT competencies, which, according to the literature review above, have not been fully addressed in Cycle Three after ADEC's educational reform. ADEC believes that English language teachers have to be well equipped with the necessary ICT knowledge and skills to make the best use of these tools for teaching the English language. The effects of having a clear idea of teachers' perceptions and attitude towards ICT tools in a structured way using international best practices can help ADEC schools plan and build their strategies that support the effective use of ICT in teaching and learning.

\section{Research Questions}

This research intended to answer the following questions:

(1) How do English language teachers perceive their ICT competencies?

(2) How do English language teachers perceive their International Society for Technology in Education (ISTE) standards competencies?

(3) What obstacles do English language teachers perceive that hinder their ICT competencies?

\section{Method}

A mixed method design utilizing the QUAN-Qual Model was used and implemented in two phases:

(1) A survey was distributed to six randomly assigned schools; three boys' and three girls' schools making about $50 \%$ of the entire 11 Cycle Three schools research population in Al Ain Educational Office. Each school has about 13 teachers making a total of 78 targeted Cycle Three English language teachers as the research 
sample. The questionnaire was adapted from ISTE NETS. It consisted of 13 sections followed by an open-ended section where teachers were given the chance to give their input.

(2) An observation was used with two randomly selected schools; one boys' and one girls' schools containing eight teachers, four male and four female teachers representing about $10 \%$ of the research sample. An observation sheet was developed based on the NETS to support the responses in the survey out of the selected perceptions of their ICT competency. Two observers were trained to use the observation sheet. Both conducted a pilot observation and then held a discussion session to see the accuracy of the observation. Each observation lasted for an entire lesson: 45 minutes, during the teachers' actual face-to-face teaching.

Results were analyzed using SPSS, descriptive statistics, and the constant comparative method of data analysis (Strauss, 1987).

\section{Participants}

Participants in this study were Cycle 3 native and non-native English language teachers as there were only a limited number of ICT studies conducted on Cycle Three in the United Arab Emirates according to the literature. In addition, Cycle Three is the most important stage in the student's life in the UAE. The learner's future studies and career is bounded by the grades he/she scores at the end of this Cycle Three. The study was carried out on Cycle Three teachers of English language in Al Ain Education Office, ADEC in UAE. The sample consisted of teachers of different years of experience, male and female, native and non-native English teachers.

Another criterion in selecting Cycle Three English language teachers as the research population was that six schools were divided equally - three boys' schools and three girls' schools selected randomly. A sample of 78 participants was targeted in this study. All participants were of different years of Cycle Three English language teaching experience. The research population was 143 English native and non-native English teachers at Cycle Three in Al Ain Education Office Schools: boys' and girls' schools, of an average of 13 teachers in each of the 11 schools; five boys and six girls' schools. The targeted sample was 78 teachers distributed among six schools, three boys and three girls' schools.

\section{Instruments}

\section{A Questionnaire}

The questionnaire was created and adapted from ISTE NETS for teachers. A five-point Likert scale was used with 1 "Never", 2 "Rarely", 3 "Sometimes", 4 "Usually", and 5 "Always". The questionnaire consisted of three parts: Part I consisted of demographic data such as gender, age, nationality, and qualifications. Part II focused on teachers' use of specific ICT tools in their classrooms. Finally, Part III focused on teachers' concerns, obstacles, and expectations from ICT in language teaching.

Overall, the questionnaire consisted of 13 main Likert-type sections dealing with the perceptions of teachers' ICT competency. The 13 sections contain 73 statements about the ICT usage, Hardware/software (items1-8), Areas of Using ICT (items 9-15), Web Authorizing Software (items 16-21), Desk Top Publishing (items 22-33), Communication Tools (items 34-38), Application Software (items 39-46), Technology Operations and Concepts (items 47-48), Planning and designing Learning Environments and Experiences (items 49-53), Teaching, Learning, and the Curriculum (items 54-57), Assessment and Evaluation (items 58-60), Productivity and Professional Practice (items 61-63), Social, Ethical, Legal, and Human Issues (items 64-68), and Major Obstacles attitude (items 69-73). 
An open-ended question was included: "List 5 points that hinder the usage of ICT in your teaching". Both the open-ended part of the questionnaire and the observations were analyzed using the constant comparative method of data analysis (Strauss \& Corbin, 1990). The researchers did not only depend on the data collected via survey, but they also supported it using random observations.

\section{Classroom Observations}

Classroom observations, constructed based on the questionnaire items, were used to collect data during English language teachers' instructions as a supporting method for data collected via the questionnaire. The constant comparative method of data analysis (Strauss \& Corbin, 1990) and content analysis were used to analyze the data.

The sample was randomly selected and several observations were conducted at different schools covering native and non-native English language teachers with different teaching experiences. Eight teachers (about $10 \%$ of the sample) are from these schools, four female and four male teachers, two native and two non-native teachers in each group, with qualifications ranging from BA to Ph.D. degrees.

\section{Data Analysis}

For the quantitative data, descriptive statistics and independent-samples T-test were used. T-test analysis was applied to investigate differences between native and non-native English teacher's knowledge, competency, and usage of ICT in English language instruction. In addition, it aimed to investigate any differences between teachers due to the number of years of experience in teaching English language using ICT and if there were any significant differences on English language teachers' ICT competencies.

An observation sheet was used to collect data focusing on the three main parts of the questionnaire which were transformed into the observation sheet with three columns for, "Yes, No, and Evidence". The observers spent a whole lesson observing the entire three-part lesson, presentation, practice, and the plenary stage. The duration of an observation was 45 minutes, the official period time in ADEC's schools. Every incident concerning using ICT and type of the tools used for showing competency in English language teaching was recorded.

For the qualitative data, the researchers applied the constant comparative method of data analysis. They first coded the data from both the open-ended part of the questionnaire and the observation sheet. Then they categorized observed ICT tools used during the English language sessions and put them in groups based on similarity. Finally, the researchers used an analysis format for listing the frequency of responses.

\section{Validity and Reliability of the Questionnaire}

The questionnaire was refereed by seven experts including one IT teacher and six native and non-native teachers making about $10 \%$ of the research sample. The "ICT Tools" and NETS standards were verified for their understandability and clarity. Meanings of each statement were verbally explained before the subjects filled in the questionnaire. Feedback from the IT teacher and the other six subjects were used to revise the questionnaire before it was administered again to the research sample in the main study.

The questionnaire content was pilot tested and revised by university instructors, including an Education Advisor (EA), Subject Support Specialist (SSS) in English language, an ICT teacher, and a number of English language native and non-native teachers.

A modified version of the NETS was used as the main component of both the questionnaire and the observation sheet. Only the first part was added to the questionnaire. The questionnaire was validated by three 
university Ph.D. holders, an Information and Technology (IT) teacher, and two Instructors of Curriculum and instructions. The content of the questionnaire was also reviewed by a board of experts, three (Educational Advisors) EA, two SSS (Subject Support Specialists), and an IT teacher were refereed to judge the content validity.

Concerning questionnaire reliability, the Alpha Cronbach was 0.96 indicating a high reliability of the questionnaire's 13 items. Concerning the observation, the researchers used the same content of the questionnaire changing the Likert scale to: yes, no, and evidence.

\section{Study Limitations}

First, this study was conducted in the Emirate of Abu Dhabi on ADEC, Al Ain Educational Office schools that are currently undergoing a thorough educational reform. This reform is aiming to facilitate all ADEC's schools with all the required ICT tools. Such a plan might not exist in other Emirates in the UAE. In addition, the sample chosen for the study is Cycle Three male and female schools in the Al-Ain Educational Office. The results cannot be generalized to other cycles. Finally, this study was implemented in the scholastic year 2011-2012. Thus, the study is limited only to public schools in one city in the UAE and in one scholastic year.

\section{Results and Discussion}

To answer question 1: "How do English language teachers perceive their ICT competencies?", the overall results showed that teachers had low mean scores on their perceptions of their ICT competencies in relation to English language teaching. The overall mean scores of the 13 sections ranged from 1.45 to 3.15 on a 5-point scale (see Table 1).

Table 1

Teachers' Perception of Their ICT Competency

\begin{tabular}{lll}
\hline Variable & Mean & SD \\
\hline Hardware/Software & 2.21 & .81 \\
Areas of Using ICT & 2.95 & 1.01 \\
Web Authorizing Software & 2.00 & 1.23 \\
Desk Top Publishing & 1.45 & .85 \\
Communication Tools & 2.45 & 1.44 \\
Application Software & 1.88 & 1.12 \\
Technology Operations and Concepts & 3.10 & 1.29 \\
Planning and designing Learning Environments and Experiences & 2.95 & 1.28 \\
Teaching, Learning and the Curriculum & 2.96 & 1.31 \\
Assessment and Evaluation & 3.06 & 1.33 \\
Productivity and Professional Practice & 3.15 & 1.37 \\
Social, Ethical, Legal and Human Issues & 2.70 & 1.32 \\
Major Obstacles & 2.64 & 1.35 \\
Total & 2.58 & 1.21 \\
\hline
\end{tabular}

These results were supported by classroom observations which showed that teachers were using only basic ICT tools such as data shows, some Internet websites for learning English, and some Microsoft Office programs (e.g., Word, Power Point, and excel). In addition, they showed some basic ICT usage for communicating with parents via Short Message Service (SMS) messages. 
Classroom observations showed that $80 \%$ of the observed teachers were using computer and data show during English language teaching classes; $75 \%$ of the observed sample were using the Internet to search for images and related topics. In addition, $50 \%$ of the sample was using the Microsoft Office Power Point Presentations during the observed sessions. Finally, about $25 \%$ of the observed teachers were using cassette players.

Investigating the results in more details, (see Table 2), some statements about the usage emerged as follows:

Table 2

Teachers' Perception of Their ICT Competencies

\begin{tabular}{|c|c|c|}
\hline Variable & Mean & $\mathrm{SD}$ \\
\hline \multicolumn{3}{|l|}{ Hardware/Software Usage } \\
\hline Microsoft Office (Word, PPT, Excel, Publisher, Access, etc.) & 3.71 & 1.49 \\
\hline Authoring software (e.g., FrontPage) & 2.14 & 1.35 \\
\hline Management programs for student data & 3.07 & 1.48 \\
\hline School Web Site & 2.08 & 1.43 \\
\hline Internet search engines for lesson planning and resource finding & 3.93 & 1.48 \\
\hline Test preparation (e.g, quiz creator) & 2.79 & 1.49 \\
\hline Total & 2.95 & 1.01 \\
\hline \multicolumn{3}{|l|}{ Areas of Using ICT } \\
\hline Computer & 3.68 & 1.35 \\
\hline Television & 1.78 & 1.10 \\
\hline VCR/VHS Tapes & 1.33 & .75 \\
\hline DVD Player & 2.18 & 1.23 \\
\hline $\mathrm{OHP}$ & 2.42 & 1.52 \\
\hline ActivBoard & 1.63 & 1.14 \\
\hline Digital cameras (still) & 2.49 & 1.26 \\
\hline Digital video cameras & 2.12 & 1.21 \\
\hline Total & 2.21 & .81 \\
\hline \multicolumn{3}{|l|}{ Web Authoring Software Usage } \\
\hline FrontPage/SharePoint designer & 1.78 & 1.13 \\
\hline Dreamweaver & 1.60 & 1.06 \\
\hline PDF & 3.03 & 1.54 \\
\hline HTML & 2.62 & 1.63 \\
\hline NetObjects Fusion & 1.45 & .96 \\
\hline Macromedia Dreamweaver & 1.49 & 1.07 \\
\hline Total & 2.00 & 1.23 \\
\hline \multicolumn{3}{|l|}{ Desk Top Publishing Programs } \\
\hline Serif PagePlus & 1.38 & .89 \\
\hline Adobe Home Publisher a & 1.70 & 1.09 \\
\hline Adobe PageMaker, Adobe FrameMaker, Adobe InDesign & 1.67 & 1.11 \\
\hline Microsoft Office Publisher & 2.33 & 1.41 \\
\hline Corel Ventura & 1.25 & .62 \\
\hline iStudio Publisher & 1.26 & .65 \\
\hline Page Stream (used to be "Publishing Partner") & 1.21 & .60 \\
\hline QuarkXPress & 1.21 & .55 \\
\hline CorelDRAW & 1.26 & .62 \\
\hline
\end{tabular}


(table 2 continued)

\begin{tabular}{|c|c|c|}
\hline Variable & Mean & SD \\
\hline \multicolumn{3}{|l|}{ Desk Top Publishing Programs } \\
\hline Fatpaint (Web-based application) & 1.22 & .63 \\
\hline OpenOffice.org & 1.49 & 1.04 \\
\hline Ready,Set,Go & 1.42 & 1.00 \\
\hline Total & 1.45 & 0.85 \\
\hline \multicolumn{3}{|l|}{ Communication Tools } \\
\hline Email & 3.52 & 1.66 \\
\hline Blogs & 2.52 & 1.54 \\
\hline Wikis & 2.41 & 1.40 \\
\hline Twitter & 1.59 & 1.13 \\
\hline Facebook & 2.21 & 1.46 \\
\hline Total & 2.45 & 1.44 \\
\hline \multicolumn{3}{|l|}{ Application Software } \\
\hline Internet Explorer & 3.40 & 1.63 \\
\hline Windows Mail & 2.36 & 1.62 \\
\hline Windows Live & 2.03 & 1.48 \\
\hline Windows Live Messenger & 1.86 & 1.43 \\
\hline Windows Live Movie Maker & 1.74 & 1.13 \\
\hline Microsoft Agent & 1.40 & .89 \\
\hline Microsoft Messenger for Mac & 1.32 & .80 \\
\hline Live Mesh & 1.00 & .00 \\
\hline Bing (search engine) & 1.78 & 1.12 \\
\hline Total & 1.88 & 1.12 \\
\hline
\end{tabular}

Regarding hardware/software, results showed that teachers use Microsoft Office more than any other hardware/software tools. However, other ICT tools like the school's website, which is supposed to be a daily ICT tool has one of the lowest means at 2.08. On the other hand, observations showed that teachers are not using Test preparation programs or Authoring software.

Similarly, results showed low perceptions in areas of using ICT with an overall mean score of 2.21 (SD $=.81$ ). Among all items, the mean score for using Computers was slightly higher (3.68). This result has been confirmed by classroom observations, showing that two-thirds of the observed teachers used computers mostly for browsing sites, downloading files and worksheets from the Internet.

The same results could be said regarding the Web authorizing software tools, where the overall mean score was 2.00. This low perception was confirmed by observations as teachers were not observed using any of the web authorizing software programs. Pertaining to that Desktop Publishing tools, results showed them as the lowest perceived items in the ICT tools. Observations indicated that teachers rarely use these tools. The same thing applies to communication tools, with an exception for email usage (mean $=3.52$ ). Observations proved that teachers are aware of the importance of being competent at using email for performing personal affairs and some of them were noticed sending tasks via emails to their students during the observed sessions.

Following a similar trend, results showed low self-perception towards application software with an overall mean of 1.88. This result was also confirmed by observations, which showed teachers were rarely using application software during the observed sessions. 
To answer question 2: "How do English language teachers perceive their ISTE standards competencies?", results showed a varied range of mean scores ranging from low to average (see Table 3 ).

Pertaining to Technology Operations and Concepts standard, results showed that teachers were neutral. The mean scores ranged between 3.40 and 1.00 which is very low. Observations have also found that the majority of the observed teachers were only using some ICT tools such as desktops and data show.

Table 3 shows a low, overall average mean score of $2.95(\mathrm{SD}=1.28)$ out of 5 items in the planning and designing learning environment and experiences. Teachers seem to lack sufficient Professional Development, which could help them plan and design the required learning environment with enough ICT experiences. Teachers' responses indicate that they use ICT poorly concerning designing lessons and are not sure if they can create an enjoyable learning environment.

Table 3

Teachers' Perception Towards Their Competencies Related to ISTE Standards

\begin{tabular}{|c|c|c|}
\hline Variable & Mean & SD \\
\hline \multicolumn{3}{|l|}{ Operations and Concepts } \\
\hline $\begin{array}{l}\text { Demonstrate introductory knowledge, skills, and understanding of concepts related to technology } \\
\text { (awareness of meaning and usage). }\end{array}$ & 3.11 & 1.36 \\
\hline $\begin{array}{l}\text { Demonstrate continual growth in technology knowledge and skills to stay abreast of current and } \\
\text { emerging technologies. }\end{array}$ & 3.08 & 1.22 \\
\hline Total & 3.10 & 1.29 \\
\hline \multicolumn{3}{|l|}{ Planning and Designing Learning Environment and Experiences } \\
\hline $\begin{array}{l}\text { Design developmentally appropriate learning opportunities that apply technology-enhanced } \\
\text { instructional strategies to support the diverse needs of learners. }\end{array}$ & 3.00 & 1.22 \\
\hline $\begin{array}{l}\text { Apply current research on teaching and learning with technology when planning learning } \\
\text { environments and experiences. }\end{array}$ & 2.92 & 1.21 \\
\hline Identify and locate technology resources and evaluate them for accuracy and suitability. & 2.97 & 1.32 \\
\hline Plan for the management of technology resources within the context of learning activities. & 2.9 & 1.3 \\
\hline Plan strategies to manage student learning in a technology-enhanced environment. & 2.97 & 1.36 \\
\hline Total & 2.95 & 1.28 \\
\hline \multicolumn{3}{|l|}{ Teaching, Learning and the Curriculum } \\
\hline $\begin{array}{l}\text { Facilitate technology-enhanced experiences that address content standards and student technology } \\
\text { standards. }\end{array}$ & .05 & 1.33 \\
\hline Use technology to support learner-centered strategies that address the diverse needs of students. & 2.97 & 1.32 \\
\hline Apply technology to develop students' higher order skills and creativity. & 2.85 & 1.30 \\
\hline Manage student learning activities in a technology-enhanced environment. & 2.96 & 1.28 \\
\hline Total & 2.96 & 1.31 \\
\hline \multicolumn{3}{|l|}{ Assessment and Evaluation } \\
\hline $\begin{array}{l}\text { Apply technology in assessing student learning of subject matter using a variety of assessment } \\
\text { techniques? }\end{array}$ & 3.21 & 1.31 \\
\hline $\begin{array}{l}\text { Use technology resources to collect and analyze data, interpret results, and communicate findings } \\
\text { to improve instructional practice and maximize student learning? }\end{array}$ & 2.86 & 1.23 \\
\hline $\begin{array}{l}\text { Apply multiple methods of evaluation to determine students' appropriate use of technology } \\
\text { resources for learning, communication, and productivity? }\end{array}$ & 3.12 & 1.44 \\
\hline Total & 3.06 & 1.33 \\
\hline \multicolumn{3}{|l|}{ Productivity and Professional Practice } \\
\hline Use technology resources to engage in ongoing professional development and lifelong learning? & 3.22 & 1.29 \\
\hline $\begin{array}{l}\text { Continually evaluate and reflect on professional practice to make informed decisions regarding the } \\
\text { use of technology in support of student learning? }\end{array}$ & 3.01 & 1.38 \\
\hline Apply technology to increase productivity? & 3.22 & 1.43 \\
\hline Total & 3.15 & 1.37 \\
\hline
\end{tabular}


(table 3 continued)

\begin{tabular}{ccc}
\hline Variable & Mean & SD \\
\hline Social, Ethical, Legal and Human Issues & & \\
\hline Model and teach legal and ethical practice related to technology use? & 2.82 & 1.36 \\
Apply technology resources to enable and empower learners with diverse backgrounds, & 2.78 & 1.24 \\
characteristics, and abilities? & 2.53 & 1.24 \\
Identify and use technology resources that affirm diversity? & 2.81 & 1.43 \\
Promote safe and healthy use of technology resources? & 2.55 & 1.32 \\
Facilitate equitable access to technology resources for all students? & 2.70 & 1.32 \\
Total & \\
\hline
\end{tabular}

Similarly, results showed an overall low mean score at 2.96 in the perception of teachers of their ICT competency in using ICT tools for teaching, learning, and the curriculum. Teachers might not be aware of the use of ICT for facilitating teaching and learning, catering for individual needs, developing higher order thinking skills, and enhancing the language learning environment. Evidence for using ICT tools for teaching, learning, and the curriculum competently were not observed during the observation session. Teachers were using basic ICT tools like data show and some MSO programs for delivering routine sessions.

Following a similar trend, "using ICT for assessment and evaluation", results show that teachers of English are not aware of the importance of using ICT for marking and recording students' summative and formative exam results. The mean score is average ranging from 2.86 to 3.21 . Observations have shown that observed teachers did not show a noticeable competency in using assessment and evaluation programs other than the Education and School Improvement Service (ESIS) program provided by ADEC.

Pertaining to Professional Development and Productivity, results showed that teachers are neutral in regard to the importance of being competent in ICTs for their professional development and productivity. The overall mean score is 3.15 out of 5 in a Likert scale. Observations neither confirm nor reject this result because there was no chance to attend PD or teachers' meetings and discussions. Finally, results of the last ISTE standard showed a low awareness of the teachers' social, ethical, legal, and human issues at an overall mean score 2.70 .

To answer question 3: "What obstacles do English language teachers perceive that hinder their ICT competencies?", results indicate that teachers are average with regards to their ICT competency and the effect of the obstacles (see Table 4). An insufficient number of ICT tools, necessary skills, shortage of time, professional development sessions, and the lack of support from administration were among the obstacles teachers perceived as barriers that affect their ICT competencies.

Observations have affirmed that teachers try to avoid using ICTs, if there are any, because the period is 45 minutes and they are required to plan three-part lessons; presentation, practice, and plenary. Thus, time is not enough to include ICT in each class. In addition, negative attitudes towards ICT tools were confirmed by the responses earlier. 
Table 4

Major Obstacles

\begin{tabular}{lll}
\hline Variable & Mean & SD \\
\hline Insufficient number of ICT tools for educational use & 3.45 & 1.57 \\
Lack of knowledge/skills in using computers/the Internet for instructional purposes & 2.15 & 1.15 \\
Insufficient time for teachers to prepare lessons using ICT & 2.92 & 1.34 \\
Inadequate administrative support at the department/school/office level & 2.82 & 1.50 \\
Feeling uncomfortable because some students are more competent with ICT than you are & 1.86 & 1.17 \\
Total & 2.64 & 1.35 \\
\hline
\end{tabular}

The overall results of the 13 sections revealed that teachers do not have a clear perception of their ICT competencies in teaching English language; the mean score (2.58).

The result of this question does not completely match with different researchers who believe that perceptions of teachers of their ICT competency have been universally recognized as an important factor for the success of technology integration in education (Rogers, 1995; Watson, 2008; Woodrow, 1992, Almekhlafi \& Almeqdadi, 2010). Teachers need to perceive the importance of being competent in ICT. As soon as they perceive the ICT tools role in language teaching, participants are expected to be using ICT in their classrooms. They can achieve that once they have been provided with the required PDs, enough time for planning and integration and ICT tools become more available to them. This symbiotic association between attitudes toward ICT and its competency and use in language instruction has been widely reported in the literature (e.g., Baylor \& Ritchie, 2002; Rogers, 1995; Hermans, Tondeur, van Braak, \& Valcke, 2008; Ajzen \& Fishbein, 1988; Kersaint, Horton, Stohl, \& Garofalo, 2003; Woodrow, 1992; Albirini, 2004).

The presence of ICT tools in the developing countries' schools is not enough. Stakeholders have the responsibility not only to supply the schools with various ICT tools, but also to foster a habit of acceptance amongst the end-users of these tools. This can be achieved through making the use of ICTs attainable by providing the teachers with the sufficient professional development sessions and enough time and encouragement. Teachers' unclear perceptions of their own ICT competencies are consistent with findings by several researchers (e.g., Ya'acob et al., 2005; Albirini, 2004; Harman \& Koohang, 2005).

This result is inconsistent with some researchers addressed in the literature review (e.g., Al-Rabaani, 2008; Eugene, 2006). The respondents' positive perceptions were clear in some T-test analyses specifically in Web Authorizing Software, Desktop Publishing, and Application Software which was in consistence with findings of research conducted by Albirini (2004), Tella, Adika, and Adeyinka (2007), Al-Zaidiyeen (2010), Ismail, Almekhlafi, and Al-Mekhlafy (2010). These results were not clear in the observation results. This supports Eugene (2006) findings who found that teachers' actual instructional practices of technology integration were found not to match their beliefs.

The results of this study stated that English language teachers are not sure of the perceptions of their ICT competencies in teaching English for Cycle Three students. Results also show that there is no significant difference in relation to the number of years of experience in teaching English language in relation to ICT competencies. However, significant differences were recognized concerning teachers' native language and native and non-native teachers' perceptions of their ICT competencies.

It can be concluded from this study that teachers' competencies of ICT are important in facilitating English language instruction and enhancing the learning of English Language. A good mastery of ICT will take 
some time when all the stakeholders work towards facilitating the ICT usage in teaching English language. Teachers should perceive their ICT competencies in saving time, efforts, and making learning English easier and more interesting. They should master ICT operation and integration in their daily face-to-face teaching.

\section{Conclusion and Recommendations}

ADEC is leading a great educational reform in the UAE aiming to reach international educational standards. This is represented by several initiatives including the role of ICT tools in education in general and ICT in English language teaching and learning in particular. This awareness is represented by equipping ADEC's schools with the required ICT tools. However, these tools will not allow the execution of the reform without taking into consideration the teachers' roles. Teachers have to be counted as the corner stone for any ICT integration. Studying the teachers' ICT needs, PDs, locating time in the curriculum for effective ICT implementation, regular meetings, and feedback from teachers' ICT integration and encouraging teachers to form positive attitudes towards ICTs are key elements for any ICT use in future English language instruction.

It is taken for granted that ADEC is aware of the above-mentioned issues. However, teachers mentioned that so far, very little is taking place concerning ICT and English language. Policy-makers should make sure that all ADEC's schools are well equipped with the latest ICT tools. The English language curriculum designers, EAs, and SSS have to encourage the ICT integration across the four cycles: Preschool, Cycle One, Cycle Two, and Cycle Three. Administrations should encourage teachers to form a positive attitude towards ICT tools and make teachers' ICT accessibility easier. EAs and SSS should encourage ICT integration to be part of the daily teaching and learning activities. Teachers are required to seek every chance to develop their ICT skills and knowledge addressing any issues hindering the ICT integration into their daily delivery. Teachers also have to be positive while handling any ICT tools, recognizing that they are made to save their time and effort. Active steps should be taken by teachers to enhance their ICT capabilities like enrolling in ICT training sessions, reading research devoted for language learning and integrating ICT, and attending any ICT forums. Students should help their teachers to make the ICT uses effective and more meaningful.

The findings obtained from this study may be specific to English language teachers in the UAE education system, but their implications are significant to other educators as well. Teachers' perceptions of their ICT competency in the current study have a special significance given the limitations characterizing the current status of ICT in UAE schools: insufficient ICT tools, lack of PDs, insufficient time for integration, and teachers' lack of ICT competence. Teachers' perceptions reflect the reality. Consequently, it is crucial for policy-makers to sustain and encourage teachers' positive attitudes towards ICT as a continuing step towards deriving the complete benefits of the ICT tools. Placing ICT tools in schools is not enough for achieving educational change. The integration of ICT into education requires equal responsibility in various aspects of education. Both ADEC policy-makers and English language teachers share a responsibility to make ICT integration into the daily curriculum delivery success.

Based on the findings of this research, it is advisable that leaders of the education reform at ADEC should endeavor revisiting the learning plan with a view to integrate the use of computer and ICT-supported instruction in teaching English language. However, ADEC can use some initiative projects like the E-Class as a proper seed for this effort. This can be implemented first by training teachers in computer literacy, then provide the adequate ICT tools in all Cycle Three schools. Also, teachers of English language should be exposed to regular seminars and computer literacy workshops to keep them abreast of computer and ICT-based instruction 
in English language. Furthermore, school administrations should list the support of local communities to secure ICT tools in all Cycles and specifically Cycle Three schools for effective teaching and learning. Ministry of Education in the UAE should also ensure that schools do not just have computers and ICT facilities; rather, they should ensure that they are effectively utilized.

The findings of this study demonstrated that the English language teachers are generally neutral in their responses regarding their ICT competency. The study was implemented on quite a big scale population where $50 \%$ of Cycle Three teachers were targeted. Thus, additional investigations surrounding the ICT competency need to be conducted. Moreover, a replication of the study can be made to assert its results on other Emirates, on larger populations and with more participants with other cycles. In addition, the study was implemented during a process of a huge reform in ADEC represented by facilitating the schools with all the necessary ICT tools. Therefore, there is a need to conduct more studies after completing ADEC's ICT reform plan.

Learners have to be willing and eager to learn using ICT tools. Administrators need to provide classes with the necessary ICT tools and make them ready for the benefit of the learners who are the main concern of the ICT competencies. However, ADEC and other stakeholders in the UAE education system should clamor for improving the quality of English Language instruction in schools through making sure that teachers have the required level of ICT mastery. This can be achieved by equipping the schools with adequate and enough ICT tools, knowledge, and skills of using ICT to teach English language.

Finally, several studies are required to investigate different English language teachers' competencies and implementing rather empirical studies to have a complete picture of the actual English language teachers' ICT competencies. Further studies are needed to investigate:

(1) Native versus non-native teachers' perceptions of their ICT competencies;

(2) The effect of variables such as teaching experience and time using the Internet;

(3) ICT infrastructure in classrooms;

(4) Access to ICT tools and resources;

(5) Teachers' attitude towards the effectiveness of ICT integration;

(6) Time constraints and ICT integration;

(7) Students' ICT skills;

(8) Administrative support for ICT integration in English classroom;

(9) ICT integration in English curriculum design.

\section{References}

Abu Dhabi Education Council. (2009). Strategic plan for P-12 education. Retrieved from http://www.adec.ac.ae/ADEC\%20Shared\%20Documents/attachments/Public\%20 schools/Strategic\%20Plans/P12-Summary-June-2009-D.pdf

Ajzen, I. (1988). Attitude structure and behavior relations. In A. R. Partkanis, S. T. Berckler, and A. G. Greenwald (Eds.), Attitude structure and function. Hillsdale, NJ: Erlbaum.

Ajzen, I., \& Fishbein, M. (1988). Theory of reasoned action-Theory of planned behavior. Florida: University of South Florida.

Albirini, A. (2004). Teachers' attitudes toward information and communication technologies: The case of Syrian EFL teachers. Computers \& Education, 47(4), 373-398.

Al-Mekhlafi, A. (2004). The effect of interactive multimedia on learning English as a second language. Proceedings of The fifth Annual UAE University Research Conference (Vol. 2), April 25-27, Al-Ain, United Arab Emirates.

Almekhlafi, A. G. (2006a). The effect of computer assisted language learning (CALL) on United Arab Emirates English as a foreign language (EFL) school students' achievement and attitude. Journal of Interactive Learning Research, 17(2), 121-142.

Almekhlafi, A. G. (2006b). Effectiveness of interactive multimedia environment on language acquisition skills of 6th grade 
students in the United Arab Emirates. International Journal of Instructional Media, 33(4), 427-442.

Almekhlafi, A. G., \& Almeqdadi, F. A. (2010). Teachers' perceptions of technology integration in the United Arab Emirates school classrooms. Educational Technology \& Society, 13(1), 165-175.

Al-Rabaani, A. H. (2008). Attitudes and skills of Omani teachers of social studies to the use of computers in instruction. International Journal of Education and Development Using Information and Communication Technology (IJEDICT), 4(4), $15-34$.

Al-Zaidiyeen, N. L. (2010). Teachers' attitudes and the level of technology use in classroom: The case of Jordan. International Education Studies, 3(2).

Bahrani, T. (2011). Speaking fluency: Technology in EFL context or social interaction in ESL context? Studies in Literature and Language, 2(2), 162-168. Retrieved from http://www.cscanada.net/index.php/sll/article/download/1758/2092

Baylor, A., \& Ritchie, D. (2002). What factors facilitate teacher skill, teacher morale, and perceived student learning in technology-using classrooms? Computers \& Education, 39(1), 395-414.

Bullock, D. (2004). Moving from theory to practice: An examination of the factors that preservice teachers encounter as the attempt to gain experience teaching with technology during field placement experiences. Journal of Technology and Teacher Education, 12(2), 211-237.

Carmen, M., María del Carmen, A. J., Emilio, R. G., Eloy G. G., \& Mar, B. D. (2003). Use of ICTs and the perception of E-learning among university students: A differential perspective according to gender and degree year group. Interactive Educational Multimedia, 7, 13-28. Retrieved $\quad$ May $20, \quad 2017 \quad$ from http://www.raco.cat/index.php/iem/article/viewFile/204235/272769

Cox, M. J., Preston, C., \& Cox, K. (1999). What motivates teachers to use ICT? Paper presented at The British Educational Research Association (BERA), University of Sussex, Brighton.

Daft, R. L., \& Lengel, R. H. (1984). Information richness: A new approach to managerial behavior and organization design. In B. Staw and L. L. Cummings (Eds.), Research in organizational behavior (Vol. 6, pp. 191-233). Greenwich, CT: JAI Press.

Daft, R. L., \& Lengel, R. H. (1986). Organizational information requirements, media richness and structural design. Management Science, 32(5), 554-571.

Daft, R. L., Lengel, R. H., \& Trevino, L. K. (1987). Message equivocality, media selection, and manager performance: Implications for information systems. MIS Quarterly, 11(3), 355-366.

Eugene, J. (2006). How teachers integrate technology and their beliefs about learning: Is there a connection? Journal of Technology and Teacher Education, 14(3), 81-597.

Harman, K., \& Koohang, A. (2005). Discussion board: A learning object. Interdisciplinary Journal of E-Learning and Learning Objects, 1(1), 67-77.

Hermans, R., Tondeur, J., van Braak, J., \& Valcke, M. (2008). The impact of primary school teachers' educational beliefs on the classroom use of computers. Computers \& Education, 51(4), 1499-1509.

Hung, D., \& Nichani, M. R. (2002). Bringing communities of practice into schools: Implications for instructional technologies from Vygotskian perspectives. International Journal of Instructional Media, 29(2), 171-183.

International Society for Technology in Education (ISTE). (2000). National educational technology standards (NETS) for teachers. Retrieved December 12, 2012 from http://cnets.iste.org/index3.html

Ismail, S., Almekhlafi, A., \& Al-Mekhlafy, M. (2010). Teachers' perceptions of the use of technology in teaching languages in United Arab Emirates Schools. International Journal for Research in Education (IJRE), 27, 2010.

ISTE National Educational Technology Standards for Teachers. (2012). Retrieved April 4, 2012 from $\mathrm{http} / / /$ cnets.iste.org/currstands/cstands-netst.html

Jimoyiannis, A., \& Komis, V. (2007). Examining teachers' beliefs about ICT in education: Implications of a teacher preparation programme. Teacher Development, 11(2), 149-173.

Kersaint, G., Horton, B., Stohl, H., \& Garofalo, J. (2003). Technology beliefs and practices of mathematics education faculty. Journal of Technology and Teacher Education, 11(4), 567-595.

Kirkup, G., \& Kirkwood, A. (2005). Information and communications technologies (ICT) in higher education teaching a tale of gradualism rather than revolution. Learning, Media, \& Technology, 30(2), 185-199.

Knezek, G., \& Christensen, R. (2002). Impact of new information technologies on teachers and students. In Networking the Learner (pp. 169-178). Chicago: Springer US.

Leach, J. (2005). Do new information and communication technologies have a role to play in achieving quality professional development for teachers in the global south? Curriculum Journal, 16(3), 293-329. 
Mumtaz S. (2000). Factors effecting teachers' use of information and communications technology: A review of the literature. Information Technology for Teacher Education, 9, 319-341.

Pelgrum, W. J. (2001). Obstacles to the integration of ICT in education: Results from a worldwide educational assessment. Computers \& Education, 37, 163-178.

Pelgrum, W. J. (2002). The effectiveness of ICT in schools: Current trends and future prospects discussion paper. Paper presented at The OECD Japan Seminar: Teachers, teacher policies and ICT.

Rogers, E. M. (1995). Diffusion of innovations (4th ed.). New York: The Free Press.

Scrimshaw, P. (2004). Enabling teachers to make successful use of ICT. Retrieved October 28, 2016 from https://core.ac.uk/download/pdf/4151892.pdf?repositoryId=161

Selvi, K. (2010). Teachers' competencies. Cultura International Journal of Philosophy of Culture and Axiology, 7(1), 167-175.

Simonsson, M. (2004). Technology use of Hispanic bilingual teachers: A function of their beliefs, attitudes and perceptions on peer technology use in the classroom. Journal of Instructional Technology, 31(3), 257-266.

So, T., \& Swantman, P. M. (2006). E-learning readiness of Hong Kong teachers. Chicago: Universi Austarial.

Strauss, A. (1987). Qualitative analysis for social scientists. Cambridge, UK: Cambridge University Press.

Telecommunications Regulatory Authority TRA. (2009). UAE ICT survey, access and use of information technology. Retrieved from http://www.tra.gov.ae/download.php?filename=UAE_ICT_Survey_en.pdf

Tella, A., Toyobo, O., Adika, O., \& Adeyinka, A. A. (2007). An assessment of secondary school teachers uses of ICTs: Implications for further development of ICT's use in Nigerian secondary schools. Online Submission, 6(3).

The Abu Dhabi Economic Vision 2030. Retrieved March 20, 2012 from http://www.tdic.ae/en/media/get/20110814_economic-vision-2030-executive-summary-mandate2propertypdf.pdf

The Abu Dhabi Education Council (ADEC). Retrieved March 20, 2012 from http://www.dubaifaqs.com/abu-dhabi-education-council.php

Trevino, L. K., Lengel, R. K., \& Daft, R. L. (1987). Media symbolism, media richness and media choice in organizations. Communication Research, 14(5), 553-574.

Watson, S. L., \& Reigeluth, C. M. (2008). Community members' perception on social, cultural changes and its implication for educational transformation in a small school district community. Journal of Organizational Transformation and Social Changes, 5(1), 45-65.

Wen, J. R., \& Shih, W. L. (2008). Exploring the information literacy competence standards for elementary and high school teachers. Computers \& Education, 50(3), 787-806.

Woodrow, J. E. J. (1992). The influence of programming training on the computer literacy and attitudes of preservice teachers. Journal of Research on Computing in Education, 25(2), 200-219.

Ya'acob, A., Nor, N., \& Azman, H. (2005). Implementation of the Malaysian smart school: An investigation of teaching-learning practices and teacher-student readiness. Internet Journal of E-Language Learning \& Teaching, 2(2), 16-25. 